\title{
Which journals should you read to keep up to date?
}

\section{Richards ${ }^{1}$}

With over 700 dental journals available worldwide, deciding which ones to read is a problem. This is usually a personal choice based on individual areas of interest. This article outlines a strategy for helping in this process and discusses whether the Scientific Citation Index, which has long been used to rank journals, is appropriate.

One method of keeping up to date with the latest advances in clinical techniques, dental materials and basic sciences has traditionally been through the reading of journals. The findings of the recent $B D J$ survey $^{1}$ of its readership confirm this with $94 \%$ of its readers considering its reports on research important and $57 \%$ finding it useful for keeping up to date clinically.

However, the $B D J$ is only one of over 700 dental journals currently available worldwide. To read all of the available dental journals would take 175 days if we spent 15 minutes (the shortest time $B D J$ readers said they spent reading the journal) per journal and one hour per day reading them. Spending fifteen minutes per journal is sufficient time to find identify any important paper but whether it is sufficient to understand them is quite another matter.

How do you decide which ones of all these journals to read on a regular basis in order to keep up to date? A strategy to do this derived from an article by Haines $^{2}$ has been outlined by Sackett $e t$ $a .^{3}$

The main elements of this approach are as follows:

- Decide which of the high circulation generalist journals (e.g. BDJ, Dental Update, JADA. Swedish Dental Journal etc) have most articles relevant to your clinical practice.

${ }^{1}$ Berkshire Health Authority, 57-59 Bath Road, Reading, RG30 2BA, UK
- Decide which of the speciality journals (Archives of Oral Biology, Caries Research, Journal of Clinical periodontology, Oral Oncology, Journal of Endodontics etc.) have most articles relevant to your clinical practice.

- Don't regularly read journals with few or no articles relevant to your clinical practice.

\section{Table 1 Scientific Citation Index 1997 Ranking}

Journal of Dental Research

Journal of Periodontology

Clinical Oral Implant Research

Journal of Clinical Periodontology

Operative Dentistry

Journal of Periodontal Research

Oral Microbiology and Immunology

8 Journal of Oral Pathology and

Medicine

9 Dental Materials

10 Oral Oncology

11 Scandinavian Journal of Dental Research

12 Critical Reviews of Oral Biology

13 Journal of Dentistry

14 Journal of Public Health Dentistry

15 Caries Research

16 Oral Surgery, Oral Medicine, Oral Pathology and Oral Radiology

17 Journal of Endodontics

18 Archives of Oral Biology

19 Community Dentistry and Oral Epidemiology

20 Journal of Prosthetic Dentistry
- Read as many of the journals having the most relevant articles as you can afford or have access to.

- Collaborate with friends and colleagues to develop and circulate complementary subscriptions.

- Develop a 'reading habit' reviewing journal with high numbers of relevant articles.

- Review current contents regularly.

How can you find out which journals you need to read regularly? You could conduct a survey of the general and specialist literature in your own field and develop your own list of journals yielding high numbers of relevant articles.
21 Journal of the American Dental Association

22 Journal of Oral and Maxillofacial Surgery

23 International Endodontic Journal

24 Swedish Dental Journal

25 European Journal of Oral Biology

26 Cleft Palate and Craniofacial Journal

27 British Journal of Oral and Maxillofacial Surgery

28 Acta Odontologica Scandanavica

29 European Journal of Orthodontics

30 Endodontics and Dental Traumatology

31 British Dental Journal

32 Journal of Oral Rehabilitation

33 International journal of Oral and Maxillofacial Surgery

34 Angle Orthodontist

35 American Journal of Orthodontics and Dentofacial Orthopaedics

36 Australian Dental Journal

37 Journal of Craniomaxillifacial Surgery

38 Journal of Dentistry for Children

39 Cranio 
The best way to start is by looking at journals that you have not previously read.

Another alternative is to use an evidence-based supplement such as this one. One of the goals of this supplement is provide the reader with a range of high quality articles related to a wide range of clinical dental practice. Each of these articles will have to pass a number of predefined criteria. But, where do we find these articles? Which journals should we review regularly for this supplement?

To answer that question the editorial team have carried out a similar exercise to that outlined above but we need your help in refining a core of the most useful journals (please forward any suggestions to: The Editors, Evidence-BasedDentistry, 64 Wimpole Street, London W1M 8AL).

One commonly used criterion for judging the quality of journals is their position in the Scientific Citation Index (SCI). This table is based on the number of times articles from particular journals that are cited in other publications. Table 1 shows the positions for 1995/6. However this table is based solely on the number of times articles in a particular journal are cited. The reason why an article is cited is not considered; it may be an excellent ground-breaking article and cited for this reason, or at the other extreme it may be cited as an example of a poor quality piece of research.

We have to take a more evidencebased approach to assessing the quality of a particular journal. This study has looked at the number of the systematic reviews and randomised controlled trial papers that have appeared in the list of journals appearing in the Scientific Citation Index (SCI).

Systematic reviews and randomisedcontrolled trials have been chosen as they represent the two highest levels of evidence in a well established hierarchy of evidence. However it is important to note that randomised-controlled trials and systematic reviews of these trials are not the only form of evidence and may not be appropriate for answering certain questions.

\section{Methodology}

Medline was searched from 1995 to May 1998 using the search strategies for systematic reviews and randomised-con- trolled trials, which can be found, at the website of the Institute of Health Sciences at the University of Oxford, (http://www.ihs.ox.ac.uk/library/fil-

Table 2 Randomised controlled trials and systematic reviews published in the top 39 journals in the Science Citations Index in 1997

\begin{tabular}{ll} 
Scientific Journal name & Number of published: \\
Citation & RCTs Systematic \\
Index & \\
1997 & \\
Ranking & \\
\hline
\end{tabular}

\section{Ranking}

$\begin{array}{llrl}2 & \text { Journal of Periodontology } & 78 & 1 \\ 3 & \text { Clinical Oral Implant Research } & 7 & 0 \\ 4 & \text { Journal of Clinical Periodontology } & 14 & 4 \\ 5 & \text { Operative Dentistry } & 4 & 0 \\ 6 & \text { Journal of Periodontal Research } & 6 & 2 \\ 7 & \text { Oral Microbiology and Immunology } & 1 & 0 \\ 8 & \text { Journal of Oral Pathology and Medicine } & 1 & 0 \\ 9 & \text { Dental Materials } & 1 & 0 \\ 10 & \text { Oral Oncology } & 5 & 4 \\ 11 & \text { Scandinavian Journal of Dental Research } & 0 & 0 \\ 12 & \text { Critical Reviews of Oral Biology } & 0 & 7 \\ 13 & \text { Journal of Dentistry } & 15 & 6 \\ 14 & \text { Journal of Public Health Dentistry } & 3 & 0 \\ 15 & \text { Caries Research } & 33 & 1 \\ 16 & \text { Oral Surgery, Oral Medicine, Oral Pathology } & 43 & 7\end{array}$

16 Oral Surgery, Oral Medicine, Oral Pathology 43

and Oral Radiology

17 Journal of Endodontics $\quad 20 \quad 0$

18 Archives of Oral Biology $3 \quad 0$

19 Community Dentistry and Oral Epidemiology $12 \quad 12$

20 Journal of Prosthetic Dentistry $25 \quad 4$

21 Journal of the American Dental Association $27 \quad 4$

22 Journal of Oral and Maxillofacial Surgery $43 \quad 1$

23 International Endodontic Journal 4

24 Swedish Dental Journal 9

25 European Journal of Oral Biology $17 \quad 0$

26 Cleft palate and Craniofacial Journal $\quad 17 \quad 2$

27 British Journal of Oral and Maxillofacial Surgery $13 \quad 1$

28 Acta Odontologica Scandinavica $11 \quad 0$

29 European Journal of Orthodontics $\quad 7 \quad 0$

30 Endodontics and Dental Traumatology 4

31 British Dental Journal $\quad 22 \quad 4$

32 Journal of Oral Rehabilitation $\quad 10 \quad 0$

33 International Journal of Oral and Maxillofacial Surgery $4 \quad 0$

34 Angle Orthodontist $14 \quad 0$

35 American Journal of Orthothodontics and $43 \quad 3$

Dentofacial Orthopaedics

36 Australian Dental Journal $11 \quad 110$

37 Journal of Craniomaxillfacial Surgery $\quad 3 \quad 2$

38 Journal of Dentistry for Children $\quad 0 \quad 0$ 
ters.html). This was then limited to the dental journals only. Searches were then conducted for each of the journals identified in Scientific Citation Index (table 1).

\section{Results}

There were 972 randomised-controlled trials and 187 systematic reviews identified in the dental subset using the search criteria. The top 39 journals in the Sci-

\section{Table 3 Journal ranking positions}

\begin{tabular}{|c|c|c|c|}
\hline $\begin{array}{l}\text { Based } \\
\text { on } \\
\text { Scientific } \\
\text { Citation } \\
\text { Index }\end{array}$ & Journal & $\begin{array}{l}\text { Based on } \\
\text { number of } \\
\text { published } \\
\text { RCTs }\end{array}$ & $\begin{array}{l}\text { Based on } \\
\text { number of } \\
\text { published } \\
\text { systematic } \\
\text { reviews }\end{array}$ \\
\hline 1 & Journal of Dental Research & 10 & 1 \\
\hline 2 & Journal of Periodontology & 1 & 16 \\
\hline 3 & Clinical Oral Implant Research & 22 & 20 \\
\hline 4 & Journal of Clinical Periodontology & 14 & 5 \\
\hline 5 & Operative Dentistry & 26 & 21 \\
\hline 6 & Journal of Periodontal Research & 24 & 11 \\
\hline 7 & Oral Microbiology and Immunology & 34 & 22 \\
\hline 8 & Journal of Oral Pathology and Medicine & 35 & 23 \\
\hline 9 & Dental Materials & 36 & 24 \\
\hline 10 & Oral Oncology & 25 & 6 \\
\hline 11 & Scandinavian Journal of Dental Research & 37 & 25 \\
\hline 12 & Critical Reviews of Oral Biology & 38 & 2 \\
\hline 13 & Journal of Dentistry & 13 & 4 \\
\hline 14 & Journal of Public Health Dentistry & 31 & 26 \\
\hline 15 & Caries Research & 5 & 17 \\
\hline 16 & $\begin{array}{l}\text { Oral Surgery, Oral Medicine, Oral Pathology } \\
\text { and Oral Radiology }\end{array}$ & 2 & 3 \\
\hline 17 & Journal of Endodontics & 9 & 27 \\
\hline 18 & Archives of Oral Biology & 32 & 28 \\
\hline 19 & Community Dentistry and Oral Epidemiology & 17 & 12 \\
\hline 20 & Journal of Prosthetic Dentistry & 7 & 7 \\
\hline 21 & Journal of the American Dental Association & 6 & 8 \\
\hline 22 & Journal of Oral and Maxillofacial Surgery & 3 & 18 \\
\hline 23 & International Endodontic Journal & 27 & 29 \\
\hline 24 & Swedish Dental Journal & 21 & 30 \\
\hline 25 & European Journal of Oral Biology & 11 & 31 \\
\hline 26 & Cleft Palate and Craniofacial Journal & 12 & 13 \\
\hline 27 & Brithsh Journal of Oral and Maxillofacial Surgery & 16 & 19 \\
\hline 28 & Acta Odontologica Scandinavica & 18 & 32 \\
\hline 29 & European Journal of Orthodontics & 23 & 33 \\
\hline 30 & Endodontics and Dental Traumatology & 28 & 34 \\
\hline 31 & British Dental Journal & 8 & 9 \\
\hline 32 & Journal of Oral Rehabilitation & 20 & 36 \\
\hline 33 & International Journal of Oral and Maxillofacial Surgery & 29 & 36 \\
\hline 34 & Angle Orthodontist & 15 & 37 \\
\hline 35 & $\begin{array}{l}\text { American Journal of Orthodontics and } \\
\text { Dentofacial Orthopaedics }\end{array}$ & 4 & 10 \\
\hline 36 & Australian Dental Journal & 19 & 38 \\
\hline 37 & Journal of Craniomaxillary Surgery & 33 & 14 \\
\hline $\begin{array}{l}38 \\
39\end{array}$ & $\begin{array}{l}\text { Journal of Dentistry for Children } \\
\text { Cranio }\end{array}$ & $\begin{array}{l}39 \\
30\end{array}$ & $\begin{array}{l}39 \\
15\end{array}$ \\
\hline
\end{tabular}

entific Citation Index account for 57\% of published dental randomised controlled trials and $35 \%$ of published systematic reviews between 1995 and May 1998. (Table 2.) In table 3 we see the ranking of journals based on the Scientific Citation Index, the percentage of randomised-controlled trials and percentage of systematic reviews. In table 4 we have presented the top 10 journals as defined by a simple average of the 3 positions, while table 5 shows the top 10 based only on evidence-based criteria.

\section{Discussion}

What does all this prove? The $B D J$ readership survey shows that journals are read for more reasons than the scientific content of their pages. Journals that publish high level of basic science

\begin{tabular}{cl}
\hline Table 4 & \\
\hline Position & Journal name \\
\hline 1 & Journal of Dental Research \\
2 & Journal of Periodontology \\
3 & Oral Surgery, Oral Medicine, \\
4 & Oral Pathology \\
5 & Journal of Clinical Periodontology \\
6 & Journal of Dentistry \\
7 & Journal of Prosthetic Dentistry \\
8 & Association \\
9 & Caries Research Dental \\
10 & Oral Onal Periodontal Research \\
\hline
\end{tabular}

\begin{tabular}{cl}
\hline Table 5 & \\
\hline Position & Journal name \\
\hline 1 & Oral Surgery, Oral medicine, \\
2 & Oral Pathology \\
3 & Journal of Dental Research \\
4 & Journal of Prosthetic Dentistry \\
5 & $\begin{array}{l}\text { Association } \\
\text { American Journal of Orthodontics }\end{array}$ \\
6 & and Dentofacial Orthopaedics \\
7 & Journal of Periodontology \\
8 & British Dental Journal \\
9 & Journal of Clinical Periodontology \\
10 & Journal of Oral and Maxillofacial \\
& Surgery \\
\hline
\end{tabular}


research are unlikely to have a high number of clinically based trials directed towards them. Equally journals which publish qualitative research are disadvantaged in a table based on randomised-controlled trials or systematic review. However rating journals on the basis of their number of citations is equally open to challenge as noted above.

Well-conducted randomised-controlled trials and systematic reviews based on them have great potential for answering questions about whether a treatment does more harm than good particularly in the clinical situation. Therefore a rating process based on the numbers seems more appropriate. However, if we only consider journals based on randomised-controlled trials or systematic reviews we will miss many good quality research articles which use a qualitative approach. Qualitative research is very important and qualitative research designs are often the most appropriate method of answering par- ticular research questions. This is why the evidence-based supplement will also endeavour to include these when appropriate and well conducted.

It is equally important that only well conducted and reported randomisedcontrolled trials or systematic reviews are included. If we were to look in detail at both the randomised-controlled trials and systematic reviews identified by the search strategy above many would not meet our quality criteria (see page 32). This supplement will endeavour to include only good quality articles relating to treatment, diagnostic testing, screening, prognosis, economic analyses and guidelines that meet predefined criteria.

Our aim will be to bring to the practising dentist summaries of the best available dental literature based on a core list of journals producing the greatest yield of useful papers. However it will not restrict itself to that list. Any core list of journals or books that are accepted unquestioningly quickly become dated and irrelevant. Because of this we will seek to both review our core list regularly and also look beyond this list. If any reader feels any particular article is important and should be included please feel free to contact the editorial office with the reference. We will then include it in our review process. Provided it passes the quality filters it will appear in the supplement.

\section{Acknowledgements}

To Christine Allot, Librarian, at the Berkshire Health Authority who conducted the medline searches.

1 Montgomery J. BDJ readership survey. $\mathrm{Br}$ Dent / 1998; 184: 563-564.

2 Haynes R B, McKibbon K A, Fitzgerald D, Guyatt G H, Walker C s, Sackett D L. How to keep up with the medical literature: II. Deciding which journals to read regularly. Ann Int Med 1986; 105: 149.

3 Sackett D L S, Haynes R B, Guyatt G H, Tugwell P. Cllnical epidemiology, a basic science for clinical medicine, 2nd edn. Boston: Little, Brown and Co., 1991.

\section{The Cochrane Collaboration: an introduction}

\section{P. Alderson ${ }^{1}$}

This brief introduction to the work of the Cochrane Collaboration is an abridged version of the full text appearing in The Cochrane Collaboration Brochure available from the following web site:

http://som.flinders.edu.au/fusa/cochrane.html

In $1972,{ }^{1}$ Archie Cochrane, a British epidemiologist, drew attention to our great collective ignorance about the effects of health care. He recognised that people who want to make more informed decisions about health care

\footnotetext{
${ }^{1}$ Deputy Director, UK Cochrane Centre, NHS Research \& Development Programme, Summertown Pavilion, Middle Way, Oxford $\mathrm{OX} 27 \mathrm{LG}, \mathrm{UK}$
}

do not have ready access to reliable reviews of the available evidence. In 1979, he wrote: ${ }^{2}$

'It is surely a great criticism of our profession that we have not organised a critical summary, by specialty or subspecialty, adapted periodically, of all relevant randomised controlled trials.'

In 1987 Cochrane referred to a systematic review of randomised controlled trials (RCTs) of care during pregnancy and childbirth as 'a real milestone in the history of randomised trials and in the evaluation of care', and suggested that other specialties should copy the methods used. ${ }^{3}$ In the same year, the scientific quality of many published reviews was shown to leave much to be desired. ${ }^{4}$ As Cochrane had emphasised, reviews of research evidence must be prepared systematically and they must be kept up-to-date to take account of new evidence.

If this is not done, important effects of health care (good and bad) will not be identified promptly, and people using health services will be ill served as a result. Without systematic, up-to-date reviews of previous research, plans for new research will not be well informed. 